\title{
Schindler Disease: The Molecular Lesion in the $\alpha$-N-Acetylgalactosaminidase Gene that Causes an Infantile Neuroaxonal Dystrophy
}

Anne M. Wang, ${ }^{\star}$ Detlev Schindler, ${ }^{\star *}$ and Robert J. Desnick ${ }^{\star}$

${ }^{*}$ Division of Medical and Molecular Genetics, Mount Sinai School of Medicine, New York 10029, and ${ }^{\ddagger}$ Department of Human Genetics, University of Würzburg, 8700 Würzburg, Federal Republic of Germany

\begin{abstract}
Schindler disease is a recently recognized infantile neuroaxonal dystrophy resulting from the deficient activity of the lysosomal hydrolase, $\alpha-N$-acetylgalctosaminidase ( $\alpha$-GalNAc). The recent isolation and expression of the full-length cDNA encoding $\alpha$-GalNAc facilitated the identification of the molecular lesions in the affected brothers from family $D$, the first cases described with this autosomal recessive disease. Southern and Northern hybridization analyses of DNA and RNA from the affected homozygotes revealed a grossly normal $\alpha$ GalNAc gene structure and normal transcript sizes and amounts. Therefore, the $\alpha$-GalNAc transcript from an affected homozygote was reverse-transcribed, amplified by the polymerase chain reaction (PCR), and sequenced. A single $G$ to $A$ transition at nucleotide 973 was detected in multiple subclones containing the PCR products. This point mutation resulted in a glutamic acid to lysine substitution in residue 325 (E325K) of the $\alpha$-GalNAc polypeptide. The base substitution was confirmed by dot blot hybridization analyses of PCR-amplified genomic DNA from family members with allele-specific oligonucleotides. Furthermore, transient expression of an $\alpha$-GalNAc construct containing the E325K mutation resulted in the expression of an immunoreactive polypeptide which had no detectable $\alpha$-GalNAc activity. (J. Clin. Invest. 1990. 86:1 7521756.) Key words: $\alpha$ - $N$-acetylgalactosaminidase $\bullet$ neuroaxonal dystrophy $\bullet$ lysosomal hydrolase $\bullet$ polymerase chain reaction
\end{abstract}

\section{Introduction}

Schindler disease is a recently recognized infantile form of neuroaxonal dystrophy resulting from the deficient activity of the lysosomal glycohydrolase, $\alpha-N$-acetylgalactosaminidase (E.C. 3.2.129; $\alpha$-GalNAc) ${ }^{1}$ (1-3). The enzymatic defect, inher-

Address reprint requests to Dr. Robert J. Desnick, Division of Medical and Molecular Genetics, Mount Sinai School of Medicine, Fifth Avenue at 100th Street, New York, NY 10029.

Received for publication 10 July 1990.

1. Abbreviations used in this paper: $\alpha$-GalNAc, $\alpha$ - $N$-acetylgalactosaminidase; CRIM, cross-reacting immunological material; 4-MU- $\alpha$ GalNAc, 4-methylumbel/liferyl- $\alpha$-GalNAc; nt, nucleotide; PCR, polymerase chain reaction.

J. Clin. Invest.

(C) The American Society for Clinical Investigation, Inc.

$0021-9738 / 90 / 11 / 1752 / 05 \quad \$ 2.00$

Volume 86, November 1990, 1752-1756 ited as an autosomal recessive trait, leads to the tissue accumulation and increased urinary excretion of glycopeptides and oligosaccharides containing $\alpha-N$-acetylgalactosaminyl moieties $(4,5)$. The disorder was described in two brothers from family $D$ who were the offspring of a consanguineous couple of German descent. The affected infants' development appeared normal for the first 9 to 12 mo of age. In the second year of life, they experienced a period of developmental delay which was followed by rapid psychomotor regression. By 3-4 yr of age, the progressive neurologic impairment led to cortical blindness, myoclonic seizures, spasticity, decorticate posturing, and profound psychomotor retardation. A cortical biopsy revealed the presence of "spheroids" in terminal axons, the unique neuropathology which classified this disease as a neuroaxonal dystrophy $(2,6)$. These clinical and morphologic manifestations in the two affected brothers were essentially identical to those in patients with Seitelberger disease, an infantile form of neuroaxonal dystrophy (6); however, the finding of normal $\alpha$-GalNAc activity in eight unrelated patients with Seitelberger disease (2) demonstrated that Schindler disease was biochemically distinct and that the infantile neuroaxonal dystrophies were genetically heterogeneous (2).

The affected homozygotes with Schindler disease had levels of $\alpha$-GalNAc activity that were less than $1 \%$ of normal in various sources as assayed with the recently synthesized substrate, 4-methylumbelliferyl- $\alpha-N$-acetylgalactosaminide (4MU- $\alpha$-GalNAc) $(2,7)$. Their parents had intermediate levels of activity consistent with being obligate heterozygotes for this autosomal recessive disorder. Using monospecific rabbit antihuman $\alpha$-GalNAc antibodies, immunoblots of fibroblast extracts from the affected brothers revealed no detectable immunoreactive enzyme protein, while extracts from their parents and a normal brother had two immunoreactive peptide species, the 48-kD monomeric and 117-kD dimeric forms of $\alpha$ GalNAc observed in normal cultured fibroblasts and in preparations of the purified human enzyme $(2,8)$. These findings suggested that the $\alpha$-GalNAc mutation in this family markedly altered the enzyme's activity and stability.

The recent isolation, sequencing, and expression of the full-length cDNA encoding human $\alpha$-GalNAc (8) permitted investigation of the molecular lesion in the $\alpha$-GalNAc gene that causes Schindler disease in this consanguineous family. The $\alpha$-GalNAc cDNA encodes a polypeptide of 411 amino acids including a signal peptide of 17 residues. Studies of human $\alpha$-GalNAc biosynthesis indicated that the precursor polypeptide was cotranslationally glycosylated in the endoplasmic reticulum, and following carbohydrate modifications and phosphorylation of its high mannose-type oligosaccharide structures in the Golgi, the mature glycopeptide of 394 amino 
acids was trafficked to the lysosome via the mannose-6-phosphate receptor-mediated pathway (9). Presumably, the mature glycopeptide is dimerized to form the $117-\mathrm{kD}$ active form in the Golgi.

In this communication, we report the specific missense mutation in the $\alpha$-GalNAc coding region which causes an infantile neuroaxonal dystrophy in this consanguineous family. This base substitution was confirmed by analysis of genomic DNA from family members and by transient expression studies. Of interest was the fact that inactive enzyme protein expressed in COS-1 cells was immunologically detectable, whereas no cross-reacting immunological material (CRIM) was present in cultured fibroblasts from the patients.

\section{Methods}

Cell lines. Primary cultures of fibroblasts and lymphoblasts were established from skin biopsies and peripheral blood samples obtained from the family $D$ members with Schindler disease and from normal controls with informed consent. The COS-1 cell lines were obtained from the American Type Culture Collection (Rockville, MD). The fibroblasts, lymphoblasts, and COS-1 cell lines were grown in RPM 1640 media supplemented with $10 \%$ fetal bovine serum, $1 \%$ penicillin, and $1 \mathrm{mg} / \mathrm{ml}$ streptomycin by standard procedures (10).

Assays of $\alpha$-GalNAc activity and protein. The $\alpha$-GalNAc activity in COS-1 cells was determined with the synthetic fluorogenic substrate $4 \mathrm{MU}-\alpha-$-GalNAc (7) as previously described (2). Protein concentration was determined by the fluorescamine assay (11). Immunobolt analyses of $\alpha$-GalNAc in transfected COS- 1 cells were performed using monospecific rabbit anti-human antibodies as described $(2,8)$.

Southern and Northern hybridization analyses. Genomic DNA was isolated from at least $10^{6}$ cultured lymphoblasts (12). The DNA was digested with restriction endonucleases (e.g., Bam HI, Pst I, Eco RI, Taq I; New England Biolabs, Beverly, MA), electrophoresed in $1 \%$ agarose, transferred to BioTrace RP charge-modified nylon 66 binding matrix (Gelman Sciences, Inc., Ann Arbor, MI) (13), and analyzed using the nick-translated $\alpha$-GalNAc cDNA as a probe (14). To determine the relative sizes and amounts of the 2.2- and 3.6-kb $\alpha$-GalNAc transcripts (8), total RNA was isolated from at least $10^{8}$ cultured lymphoblasts (15). RNA samples were electrophoresed in $1 \%$ agarose/formaldehyde denaturing gels (16), transferred to the BioTrace membranes described above, and analyzed with the radiolabeled $\alpha$-GalNAc riboprobe synthesized with SP6 polymerase from the $\alpha$-GalNAc 2.2-kb cDNA cloned into the pGEM $4 Z$ vector (Promega Biotec, Madison, WI).

DNA amplification and sequencing of the mutant allele. Sense and antisense oligonucleotide primers designed to amplify the entire coding region of the $\alpha$-GalNAc gene in two overlapping fragments were synthesized on a model 380B DNA synthesizer (Applied Biosystems, Inc., Foster City, CA). As shown in Fig. 1, the $5^{\prime}$ region of the $\alpha$-GalNAc transcripts (cDNA nucleotide [nt] -54 to 689 [8]) was amplified using the 32-mer sense primer, P1 (5'-AGTAGTGAATTCCTGATACACGCAGACCAGAT- $3^{\prime}$ ), corresponding to $\alpha$-GalNAc nt-34 to -53 with an additional $12 \mathrm{nt}$ which included an Eco RI site and a 32-mer antisense primer, P2 (5'-AGTAGTAAGCTTTTCAGGATGGAGAGCTCGCT-3'),corresponding to $\alpha$-GalNAc cDNA nt 670-689 with a Hind III site for force subcloning. The $3^{\prime}$ region of the coding sequence (cDNA nt 595 to 1292) was amplified using a 32-mer sense primer, P3 (5'-AGTAGTGAATTCAGGGTGAACTACAGTCTGCT-3), corresponding to nt 595-614 with an Eco RI site and a 32-mer antisense primer, P4 (5'-AGTAGTAAGCTTGCTCCATGGTCTAGGCTCAG-3'), corresponding to nt 1273-1292 and containing a Hind III site. Total RNA $(10 \mu \mathrm{g})$ was reverse-transcribed to cDNA using the BRL cDNA Synthesis Kit (Bethesda Research Laboratories, Gaithersberg, MD). One-fourth of the cDNA product was polymerase chain reaction (PCR)-amplified (17) using the Gene-

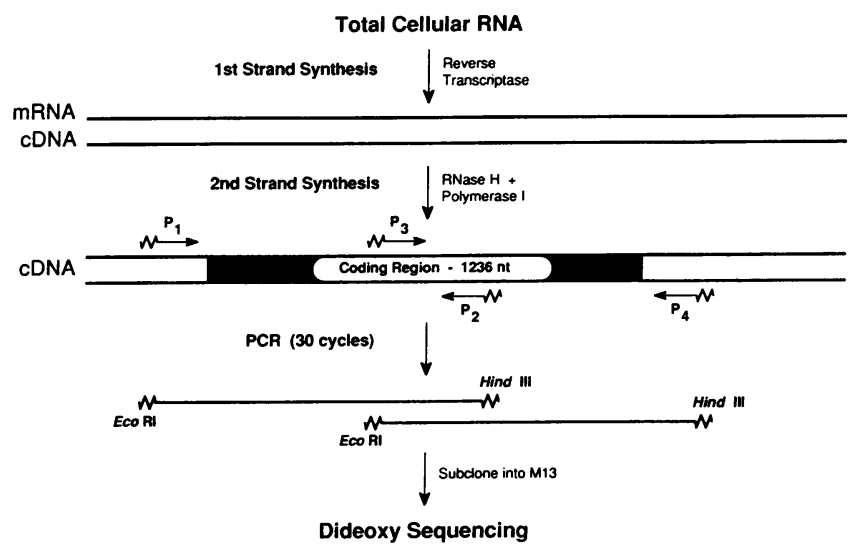

Figure 1. Strategy for the identification of the specific molecular lesion in Schindler disease. Total RNA was isolated from lymphoblasts and reverse-transcribed to CDNA using oligo $\mathrm{dT}$ and reverse transcriptase. The $\alpha$-GalNAc coding region was PCR-amplified in two overlapping fragments, cloned into the M13 sequencing vectors, and sequenced in both orientations. See text for details.

Amp DNA Amplification Reagent Kit (Perkin-Elmer Cetus, Norwalk, CT) and $1 \mu \mathrm{M}$ of each primer. Each of the 30 PCR cycles consisted of denaturation at $94^{\circ} \mathrm{C}$ for $1 \mathrm{~min}$; annealing at $37^{\circ} \mathrm{C}$ for $2 \mathrm{~min}$; and extension at $60^{\circ} \mathrm{C}$ for $7 \mathrm{~min}$. Each PCR product was phenol extracted, ethanol precipitated, resuspended in $20 \mu \mathrm{l} \mathrm{H}_{2} \mathrm{O}$, and then $2 \mu \mathrm{l}$ was analyzed by electrophoresis in a $1.8 \%$ agarose gel. The remaining $18 \mu \mathrm{l}$ was digested with Eco RI and Hind III and force-subcloned into the M13 mp18 and 19 vectors (18). Clones containing the PCR products were identified by plaque hybridization using the nick-translated $\alpha$ GalNAc cDNA (14). Single-stranded template was isolated (18) from six separate M13 clones, and each was sequenced in both orientations by the dideoxy chain-termination method (19) using universal and $\alpha$-GalNAc-specific primers.

Oligonucleotide hybridization of genomic DNA. Genomic DNAs (1 $\mu \mathrm{g})$ from affected homozygotes, their obligate heterozygous parents, and normal individuals were PCR-amplified using primers that flanked the region of the mutation by the conditions described above. The $5^{\prime}$ sense primer was a 20-mer (5'-TGATGTCCACAGACCTGCGT-3') corresponding to nt 842-861 and the $3^{\prime}$ antisense primer was a 20 -mer (5'-TCAGCTGCAGGACCGATATG-3') corresponding to nt 1005-1024 of the $\alpha$-GalNAc full-length cDNA, pAGB-3 (8). Normal and mutation-specific oligonucleotide probes (21-mers) were synthesized with the sequences 5 '-TCTCTCATCGAAGTGTACATG- ${ }^{\prime}$ and 5'-TCTCTCATCAAAGTGTACATG-3', respectively. Dot blots were denatured, hybridized, and washed as described (20).

Computer-assisted analyses. Local secondary structure for both the normal and mutant enzymes were predicted by the algorithms of Chou and Fasman (21) and Garnier et al. (22) using the University of Wisconsin Computer Group software (23). A region of 20 amino acids surrounding the site of the glutamic acid to lysine substitution was used for the prediction of the local secondary structure.

Construction of the mutant $c D N A$ and transient expression of the mutation in COS-1 cells. A Bam HI-Kpn I fragment containing the $\mathrm{G}$ to A substitution from an M13 clone was used as a cassette to replace the corresponding region in the full-length $\alpha$-GalNAc cDNA (8). The sequence of this construct was confirmed by dideoxy sequencing, and then the construction was subcloned into the eukaryotic expression vector p91023(B) (24) kindly provided by Dr. R. J. Kaufmann, Genetics Institute, Cambridge, MA. COS-1 cells were transfected with the mutant construct, designated p91-AGB-973A (25), harvested at $72 \mathrm{~h}$ posttransfection, and then assayed for activity and immunoreactive protein as previously described (2). 


\section{Results}

Molecular characterization of the $\alpha$-GalNAc mutation in family $D$. In order to characterize the nature of the mutation in family D, Southern analysis was performed with four restriction endonucleases on genomic DNA from the affected homozygotes, their obligate heterozygous parents, and unrelated normal individuals. No obvious gene rearrangements were observed (data not shown). It is interesting that the family D members were polymorphic at the $\alpha$-GalNAc locus for two restriction endonuclease sites, Bam $\mathrm{HI}$ and Taq I; these polymorphic sites were found in 16 of 40 (45\%) and 2 of $76(2.6 \%)$ normal Caucasian alleles, respectively. Northern analysis of total RNA from family D members and from normal individuals revealed the presence of the two $\alpha$-GalNAc transcripts of $\sim 2.2 \mathrm{~kb}$ and $\sim 3.6 \mathrm{~kb}$. Since the affected brothers had transcripts of normal size and abundancy, the possibility of promotor, mRNA processing, or stability mutations was excluded. These findings, and the fact that no $\alpha$-GalNAc immunoreactive enzyme protein was detected in fibroblasts from the affected homozygotes, suggested that the mutation causing Schindler disease was most likely due to point mutations or small insertions or deletions in the coding region of the $\alpha$-GalNAc gene.

To identify the $\alpha$-GalNAc mutation in this family, total RNA isolated from the cultured lymphoblasts of an affected sibling was reverse transcribed, PCR-amplified, and sequenced in both orientations as described above (Fig. 1). Sequence analysis of all 12 subclones revealed a $G$ to $A$ transition at nucleotide 973 which caused a glutamic acid to lysine substitution at residue 325 (Fig. 2). This substitution, designated E325K, was confirmed by hybridization of allele-specific oligonucleotides with PCR-amplified genomic DNA from the affected homozygotes, the obligate heterozygous parents and normal individuals. As shown in Fig. 3, the mutation-specific oligonuceotide hybridized only with the amplified genomic

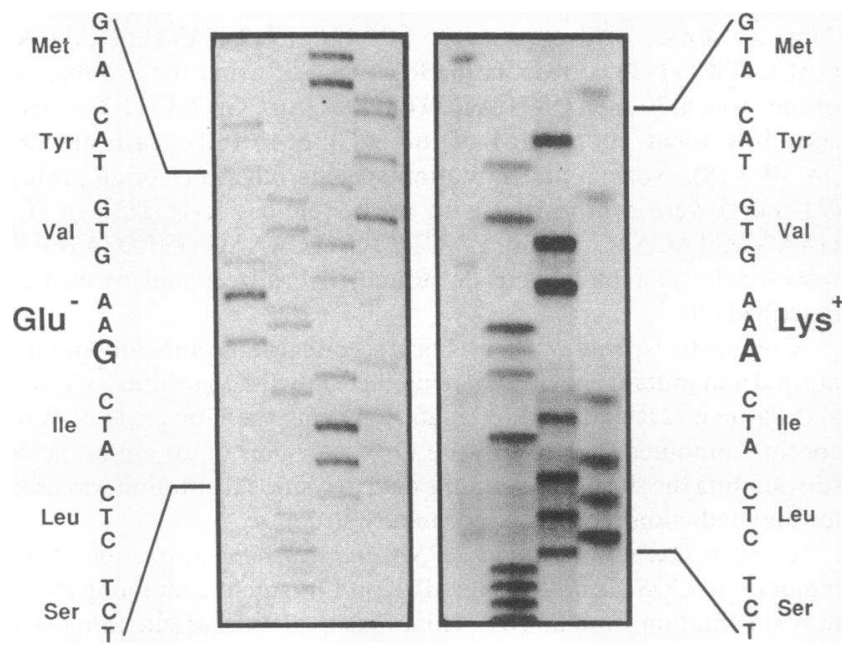

Figure 2. Partial DNA sequence of the reverse-transcribed and PCRamplified $\alpha$-GalNAc transcript from an affected family D homozygote. Compared to the normal cDNA sequence (left), a G to A transition at $\mathrm{nt} \mathbf{9 7 3}$ that predicted a glutamic acid to lysine substitution at residue 325 was identified in all subclones containing the $\alpha-\mathrm{Gal}-$ NAc PCR product from the affected homozygote. See text for details.

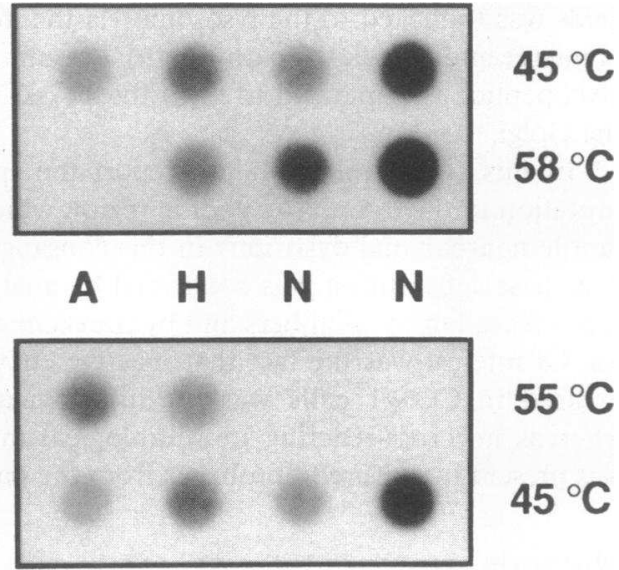

Figure 3. Allele-specific oligonucleotide hybridization of PCR-amplified genomic DNA isolated from lymphoblasts of an affected homozygote $(A)$, his obligate heterozygous parent $(H)$, and two unrelated normal individuals $(N)$. Hybridization was carried out initially at $45^{\circ} \mathrm{C}$ and the filters were washed at the indicated temperatures for allele-specific binding. See text for details.

sequence from the affected homozygotes. In support of this finding, the genomic PCR product from each of their parents hybridized with both the normal and mutation-specific oligonucleotides.

Expression of the mutation in COS-1 cells. To further characterize this mutation, the Bam HI-Kpn I fragment (nt 921-1193) from an M13 subclone containing the mutant allele was introduced as a cassette into the full-length pAGB-3 cDNA. The mutated cDNA, designated pAGB-973A, was sequenced and then subcloned into the eukaryotic expression vector p91023(B). This expression construct, p91-AGB-973A, was transfected into COS-1 cells, and $72 \mathrm{~h}$ after transfection the cells were harvested and extracts were assayed for $\alpha$-GalNAc activity and immunoreactive enzyme protein. Immunoblot analysis revealed the presence of immunologically detectable protein with a subunit molecular weight of $\sim 48 \mathrm{kD}$ (Fig. 4). However, $4 \mathrm{MU}-\alpha-$ GalNAc activity in COS-1 cells was not increased above endogenous COS- 1 cell levels, whereas the

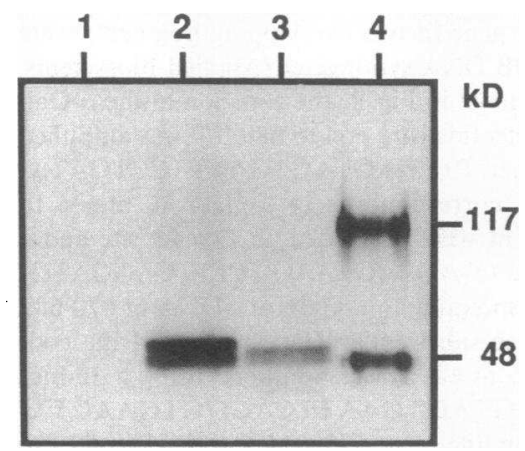

Figure 4. Immunoblot of transiently expressed $\alpha$-GalNAc constructs p91-AGB-3 and p91AGB-973A in COS-1 cells. Lane 1 , mock transfection minus DNA; lane 2, p91AGB-3; lane 3, p91AGB-973A; lane 4, $117-\mathrm{kD}$ dimeric and 48-kD monomeric $\alpha$ GalNAc purified from human lung (8). Note that the expressed normal and mutant $\alpha$-GalNAc subunits are doublets that appear to have slightly higher molecular weights than the purified enzyme subunit from human lung, presumably due to slightly different glycosylation by COS-1 cells. 
Table I. Transient Expression of Normal and E325K $\alpha-N$-Acetylgalactosaminidase cDNAs

\begin{tabular}{lc}
\hline \multicolumn{1}{c}{ Construct } & $\alpha$-GalNAc activity* \\
\hline & $U / m g$ protein \\
p91-AGB-3 & \\
Mean & 661 \\
Range $(n=6)$ & $105-2415$ \\
p91-AGB-973A & \\
Mean & 44 \\
Range $(n=6)$ & $27-65$ \\
Mock transfection (no DNA) & \\
Mean & 36 \\
Range $(n=6)$ & $31-64$ \\
\hline
\end{tabular}

* The reaction mixture contained $0.8 \mathrm{mM} 4 \mathrm{MU}-\alpha$-GalNAc as substrate.

normal construct, p91-AGB-3, expressed immunodetectable protein that had an $\alpha$-GalNAc activity that was 20 -fold greater than the mean endogenous level or the mean level in mocktransfected COS-1 cells (Table I).

Secondary structure analyses. Computer-assisted regional secondary structural analysis of residues 310 to 330 predicted differences in the normal and E325K structures $(21,22)$. As illustrated in Fig. 5, the glutamic acid to lysine substitution in E325K extended a $\beta$-pleated sheet region $5^{\prime}$ to the mutation, and created a short $\alpha$-helical structure which included the mutation.

\section{Discussion}

Schindler disease is the only neuroaxonal dystrophy in which the biochemical defect has been identified. Although the deficient $\alpha$-GalNAc activity results in the lysosomal accumulation and urinary excretion of $\alpha$-GalNAc-containing oligosaccharides and glycopeptides, the nature of the biochemical alterations in the brain that cause the unique neuroaxonal pathol-
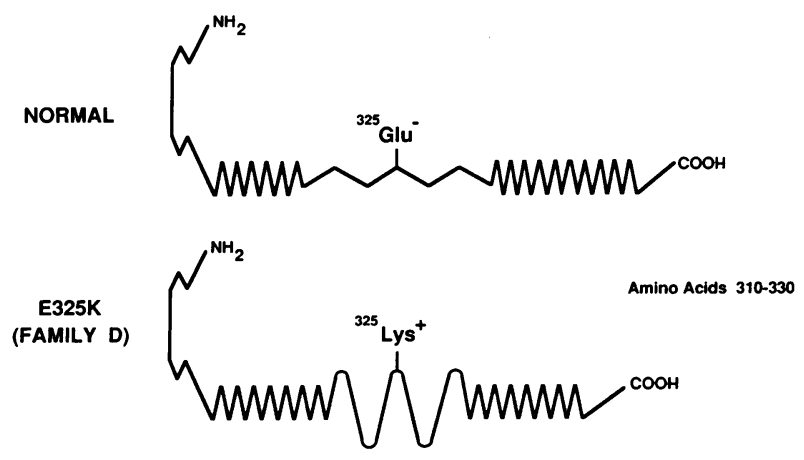

$M M$ = $\beta$-pleated sheet $\widetilde{W}=$ randolix

Figure 5. Computer-assisted secondary structure predicted for normal and E325K $\alpha$-GalNAc residues 310-330. Note that the E325K mutation replaced a random coil region with an $\alpha$-helical structure. See text for details. ogy has not been determined. The recent isolation of the full-length cDNA encoding $\alpha$ GalNAc permitted the characterization of the molecular lesion causing the enzymatic defect in the first family with this inherited disorder. Southern and Northern hybridization analyses of DNA and RNA from the affected homozygotes revealed no gross chromosomal rearrangements and transcripts of normal size and abundancy. Subsequent reverse-transcription, amplification, and sequencing of the $\alpha$-GalNAc transcript from an affected homozygote revealed a single $G$ to $A$ transition at nt 973 in the coding region. This transition, which predicted a glutamic acid to lysine substitution at residue 325 of the $\alpha$-GalNAc polypeptide (E325K), was confirmed in genomic DNA from both affected homozygotes and their obligate heterozygous parents using allele-specific oligonucleotides. These results indicated that the affected homozygotes were homoallelic for this mutation, consistent with the fact that the affected homozygotes were the offspring of a consanguineous marriage.

The nonconservative E325K mutation altered the enzyme polypeptide and tertiary conformation (e.g., by the insertion of a short $\alpha$-helical region as predicted in Fig. 5) such that no activity or immunoreactive enzyme protein was detectable in cultured cells from the affected homozygotes. In contrast, transfection of the mutant p91-AGB-973A $\alpha$-GalNAc cDNA into COS- 1 cells resulted in the transient expression of a polypeptide which was immunoreactive, but had no detectable enzymatic activity toward the specific $4 \mathrm{MU}-\alpha$-GalNAc substrate. The fact that fibroblast extracts from the affected homozygotes were CRIM-negative suggested that the E325K mutation caused the enzyme polypeptide to be unstable and rapidly degraded in cultured cells and, presumably, in vivo. A similar finding of a CRIM-negative mutant protein in fibroblasts that was immunologically detectable when transiently expressed in COS- 1 cells has been observed for a mutation in the vitamin D receptor gene (26). The detection of immunoreactive enzyme in the COS- 1 cells most likely reflects the "pulsed" synthesis of the altered human polypeptide that then is degraded due to instability and/or the inability of the polypeptide subunits to associate into more stable multimeric forms. This may be the case for the $\alpha$-GalNAc polypeptide since the homodimeric form is extremely stable (8). Thus, the classification of a mutation as CRIM- negative based on studies of the patient's cells or tissues does not imply that the enzyme is not synthesized. Subsequent stable expression of normal and mutant constructs may provide sufficient quantities of these enzyme proteins for comparison of their physical and kinetic properties. For example, such studies may determine if the E325K mutation alters subunit association, the interaction with different substrates, and/or other factors in the catalytic complex.

The identification of this molecular lesion in the family D homozygotes will permit accurate heterozygote detection for relatives using allele-specific oligonucleotides. Molecular heterozygote diagnosis will be particularly valuable since there was significant overlap in the ranges of enzymatic activities in various sources for family $\mathrm{D}$ obligate heterozygotes and normal individuals. Moreover, since family $\mathrm{D}$ is from a small inbred village in which previous children with the Schindler phenotype were known, screening can be performed to identify carriers and provide the opportunity for accurate prenatal diagnosis, if requested. 
Although Schindler disease is the only neuroaxonal dystrophy in which the biochemical and molecular defects have been identified, the nature of the accumulated neuronal substrate(s) and the pathophysiologic events that lead to the unique spheroid formations in the distal axons remain unknown. Further studies of this disease may provide insight into the normal role of $\alpha$-GalNAc-containing glycoconjugates and $\alpha$-GalNAc in neuronal metabolism and/or transport.

\section{Acknowledgments}

This research was supported in part by a research grant from the National Institutes of Health (5 R01 DK-34045), a General Clinical Research Center grant (RR-00071) from the National Center for Research Resources, National Institutes of Health, and a grant (1-589) from the March of Dimes Birth Defects Foundation. A. Wang is the recipient of a predoctoral fellowship from the National Institutes of Health (5 T32 HD-07105).

\section{References}

1. van Diggelen, O. P., D. Schindler, R. Willemson, M. Boer, W. J. Kleijer, J. G. M. Huijmans, W. Blom, and H. Galjaard. 1988. $\alpha-N$ acetylgalactosaminidase deficiency, a new lysosomal storage disorder. J. Inherited Metab. Dis. 11:349-357.

2. Schindler, D., D. F. Bishop, D. E. Wolfe, A. M. Wang, H. Egge, R. U. Lemieux, and R. J. Desnick. 1989. Neuroaxonal dystrophy due to lysosomal $\alpha-N$-acetylgalactosaminidase deficiency. $N$. Engl. J. Med. 320:1735-1740.

3. Desnick, R. J., and D. F. Bishop. 1989. Schindler disease: $\alpha-N$ acetylgalactosaminidase deficiency. In The Metabolic Basis of Inherited Disease. C. R. Schiver, A. L. Beaudet, W. S. Sly, and D. Valle, editors. McGraw-Hill, Inc., New York. 1751-1796.

4. Linden, H. U., R. A. Klein, H. Egge, J. Peter-Katalinic, J. Dabrowski, and D. Schindler. 1989. Isolation and characterization of sialic acid-containing glycopeptides of the $O$-glycosidic type from the urine of the two patients with hereditary deficiency in $\alpha$-GalNAc activity. Biol. Chem. Hoppe-Seyler. 370:661-672.

5. Schindler, D., T. Kanzaki, and R. J. Desnick. 1990. A method for the rapid detection of urinary glycopeptides in $\alpha-N$-acetylgalactosaminidase deficiency and other lysosomal storage diseases. Clin. Chim. Acta. 190:81-92.

6. Seitelberger, F. 1986. Neuroaxonal dystrophy: its relation to aging and neurological disease. In Handbook of Clinical Neurology. Vol. 49. P. J. Vinken, G. W. Bruyn, and H. L. Klawans, editors. Elsevier Science Publishers B. V., Amsterdam. 391-415.

7. Lemieux, R. U., and R. M. Ratcliffe. 1979. The azidonitration of tri-O-acetyl-D-galactal. Can. J. Chem. 57:1244-1251.

8. Wang, A. M., D. F. Bishop, and R. J. Desnick. Human $\alpha-N$-acetylgalactosaminidase: molecular cloning, nucleotide sequence and expression of a full-length cDNA. J. Biol. Chem. In press.

9. Sweeley, C. C., N. C. LeDonne, and P. W. Robbins. 1983. Post-translational processing reactions involved in the biosynthesis of lysosomal $\alpha-N$-acetylgalactosaminidase in cultured human fibroblasts. Arch. Biochem. Biophys. 223:158-165.

10. Bernstein, H. S., D. F. Bishop, K. H. Astrin, R. Kornreich,
C. M. Eng, H. Sakuraba, and R. J. Desnick. 1989. Fabry disease: six gene rearrangements and an exonic point mutation in the $\alpha$-galactosidase gene. J. Clin. Invest. 83:1390-1399.

11. Bishop, D. F., and R. J. Desnick. 1981. Affinity purification of $\alpha$-galactosidase A from human spleen, placental and plasma with elimination of pyrogen contamination. J. Biol. Chem. 256:1307-1316.

12. Aldridge, J., L. Kunkel, G. Bruns, U. Tantravahi, M. Lalande, T. Brewster, E. Moreau, M. Wilson, W. Bromley, T. Roderick, and S. A. Latt. 1984. A strategy to reveal high frequency RFLPs along the human X chromosome. Am. J. Hum. Genet. 36:546-564.

13. Southern, E. M. 1975. Detection of specific sequences among DNA fragments separated by gel electrophoresis. J. Mol. Biol. 98:503-517.

14. Maniatis, T., E. F. Fritsch, and J. Sambrook. 1982. Molecular Cloning: A Laboratory Manual. Cold Spring Harbor Laboratories, Cold Spring Harbor, NY. 545 pp.

15. Chirgwin, J. M., A. E. Pryzbyla, R. J. MacDonald, and W. J. Rutter. 1979. Isolation of biologically active RNA from sources enriched in ribonuclease. Biochemistry. 18:5294-5298.

16. Lehrach, H., D. Diamond, J. M. Wozney, and H. Doedtker 1977. RNA molecular weight determinations by gel electrophoresis under denaturing conditions, a critical look. Biochemistry. 16:47434751.

17. Saiki, R. K., S. Scharf, F. Faloona, K. B. Mullis, G. T. Horn, H. A. Erlich, and N. Arnheim. 1985. Enzymatic amplification of $\beta$ globin genomic sequences and restriction site analysis for diagnosis of sickle cell anemia. Science (Wash. DC). 230:1350-1359.

18. Messing, J., and J. Vieira. 1982. A new pair of M13 vectors for selecting either DNA strand of double digest restriction fragments. Gene (Amst.). 19:269-276.

19. Sanger, F., A. R. Coulson, B. G. Garrell, A. J. H. Smith, and B. A. Roe. 1980. Cloning in single-stranded bacteriophage as an aid to rapid DNA sequencing. J. Mol. Biol. 143:161-178.

20. Theophilus, B., T. Latham, G. A. Grabowski, and F. I. Smith. 1989. Gaucher disease: molecular heterogeneity and phenotype-genotype correlations. Am. J. Hum. Genet. 45:212-225.

21. Chou, P. Y., and G. D. Fasman. 1978. Prediction of the secondary structure of proteins from their amino acid sequence. Adv. Enzymol. Relat. Areas Mol. Biol. 47:45-147.

22. Garnier, J., D. J. Osguthorpe, and B. Robson. 1978. Analysis of the accuracy and implications of simple methods for predicting the secondary structure of globular proteins. J. Mol. Biol. 120:97-120.

23. Wolf, H., S. Modrow, M. Motz, B. A. Jameson, G. Hermann, and B. Fortsch. 1988. An integrated family of amino-acid sequenceanalysis programs Comput. Appl. Biosci. 4:187-191.

24. Wong, G. G., J. S. Witek, P. A. Temple, K. M. Wilkins, A. C Leary, D. P. Luxenberg, S. S. Jones, E. L. Brown, R. M. Kay, E. C. Orr et al. 1985. Human GM-CSF: molecular cloning of the complementary DNA and purification of the natural and recombinant proteins. Science (Wash. DC). 228:810-813.

25. Chen, C., and H. Okayama. 1987. High efficiency transformation of mammalian cells by plasmid DNA. Mol. Cell. Biol. 7:27452752.

26. Ritchie, H. H., M. R. Hughes, E. T. Thompson, P. J. Malloy, Z. Hochberg, D. Feldman, J. W. Pike, and B. W. O'Malley. 1989. An ochre mutation in the vitamin $D$ receptor gene causes hereditary 1,25-dihydroxyvitamin $\mathrm{D}_{3}$-resistant rickets in three families. Proc Natl. Acad. Sci. USA. 86:9783-9787. 